\title{
Mogućnosti primjene tehnologije GPS-a u sociološkim istraživanjima
}

\author{
Josip Ježovita \\ Hrvatsko katoličko sveučilište, Zagreb, Hrvatska \\ e-mail: josip.jezovita@unicath.hr
}

\section{Erik Brezovec \\ Sveučilište u Zagrebu, Fakultet hrvatskih studija, Hrvatska \\ e-mail:ebrezovec@hrstud.hr}

\author{
Lucija Mihaljević \\ Hrvatsko katoličko sveučilište, Zagreb, Hrvatska \\ e-mail: lucija.mihaljevic@unicath.hr
}

SAŽETAK U ovom teorijsko-istraživačkom radu analiziraju se mogućnosti upotrebe metodologije GPS-a u istraživanju na području društvenih znanosti. Rad karakteriziraju dva temeljna cilja. Prvi je cilj prikazati načine primjene tehnologije GPS-a u istraživačkoj praksi i na temelju toga predstaviti što se upotrebom te tehnologije i metode može postići. Drugi cilj usmjeren je na analizu praktične valjanosti teorije ubrzane modernosti. Teorije koje u fokusu imaju ubrzanu modernost iako su relativno apstraktne, mogu se potvrditi određenim empirijskim postupcima. Jedan od takvih postupaka jest i ovo istraživanje, kojim se upotrebom tehnologije GPS-a istražuje dinamika kretanja pojedinaca u urbanom prostoru Grada Zagreba. Uz upotrebu te tehnologije moguće je analizirati dinamiku kretanja ljudi s obzirom na prostorno-vremenski kontekst. Metoda ovoga istraživanja bilo je praćenje sudionika istraživanja njihovim pametnim mobilnim uređajima s ugrađenim sustavom GPS-a. Deset sudionika istraživanja pristalo je na praćenje njihova GPS-a 30 dana. Iz rezultata istraživanja proizlazi različita dinamika kretanja. Naime, sudionici su tijekom radnog dijela tjedna bilježili visoku razinu prostorne dinamike u zgusnutom vremenskom okviru (što ide u prilog teoriji ubrzane modernosti), dok su se tijekom vikenda u većoj mjeri zadržavali u svojim domovima. Istraživanjem se postavljaju četiri dimenzije, između ostalih, koje se tehnologijom GPS-a mogu obuhvatiti u okviru društvenih znanosti te se postavljaju metodološke smjernice za kombiniranje tehnologije GPS-a s drugim metodama.

Ključne riječi: GPS, metodologija, ubrzana modernost, prostorna dinamika. 


\section{Uvod}

U svom radu o novom, globalnom kontekstu sociologije Cifrić (1995.) spominje (re) aktualizaciju pitanja predmetnosti sociologije kao znanosti. To se pitanje, naime, ne mora nužno ograničiti na suvremeni kontekst. Problematika tog tipa mogla bi se proširiti na cjelokupnu povijest sociološke misli. Od samih početaka ustrojstva sociologije kao znanosti postojale su poteškoće u definiranju osnovnog predmeta i metoda kojima bi sociolog trebao dokučiti činjeničnost/značenje društvenih sustava, interakcije, tj. općeg djelovanja osobe. Ipak, današnji vremenski kontekst po mnogočemu je specifičan. Nameću se brojne nove pojavnosti koje se u svojoj biti mogu okarakterizirati kao društvene (npr. društvene mreže, internet, rizik, neutaživost želja). Moglo bi se reći da se društveni svijet širi tako da se dosad nezamislivim pojavnostima daje etiketa društvenoga (bilo interakcije, strukture ili pak tehnologije).

Tehnologija je kroz povijest razvoja moderne misli bila dio društvenosti, u službi čovjeka, no danas taj odnos poprima dijalektičke dimenzije (u smislu da čovjek ostvaruje tehnologiju, ali i tehnologija ostvaruje čovjeka). Drugim riječima, interakcijski proces između čovjeka, društva i tehnologije više nije hijerarhijski. U tom su smjeru noviji teorijski koncepti pod nazivom Acter Network Theory (vidi Latour, 2005.). Latour (2005.) u svojoj teoriji u procese društvenog života i interakcije, u razvoj društvene strukture uključuje i neljudske aktere (kao što su priroda i tehnologija). Svi akteri ravnopravno sudjeluju u stvaranju društvenog života. Takva modernost, u kojoj je tehnologija jedan od društvenih aktera, zahtijeva prilagodbu (u ovom slučaju) metodologije društvenih znanosti, a prije svega sociologije. Kako bi taj „odbjegli svijet” (Giddens, 2005.) bio dostupan sociologiji za proučavanje, ona se treba osuvremeniti na isti način na koji se „modernizirao" suvremeni čovjek. Drugim riječima, na sociologiji je kao znanosti da se suvremenim tehnološkim dostignućima koristi u objašnjenjima današnje društvene stvarnosti. Imajući na umu te kontekstualne napomene, svrha je ovog rada uvidjeti nove metodološke mogućnosti u sociološkim istraživanjima.

\section{Teorijski okvir istraživanja}

Unatoč činjenici da je društvena dinamika sveprisutna kroz povijest društvenih odnosa, težnja je suvremenih sociologa da doba u kojemu žive obilježe odstojanjem od svih prethodnih povijesnih etapa (npr. događa se nešto do sada neviđeno). Takva vrsta fokusiranosti na specifičnost društvene dinamike našeg vremena (iako je na sličan način o svojem dobu pisao Auguste Comte) u mnogim slučajevima ostaje lišena empirijske potvrde. Ponekad je za empirijsku validaciju neke teorije dovoljan osvrt na stvarnost u kojoj se nalazimo. No tada takva teorija često ostaje podložna nespretnim generalizacijama ili se pak zadržava u okvirima onoga što postmodernisti nazivaju velikim narativom, (p)ostajući samoj sebi svrha. $S$ druge strane, inzistiranje na dominaciji empirizma nad teorijom sociologiju lišava apstraktnosti potrebne za provedbu istraživanja 
(npr. u fazi konceptualizacije). U tom smislu istraživanja postaju isprazne deskriptive ili pak objašnjenja zatečenog stanja bez konkretnog razumijevanja ${ }^{1}$. Sintezom teorije i empirijskih podataka rješavaju se predstavljene poteškoće svake od spomenutih dimenzija sociološkog rada. Upravo je ta sinteza osnovno polazište rada u kojem se na temelju sustava GPS-a razmatraju dinamički procesi s kojima se suvremeno društvo suočava. Konkretnije, u ovom radu upotrebom metodologije GPS-a analiziraju se pristupi prostoru i vremenu specifični za teorije ubrzane modernosti 21. stoljeća.

Suvremena modernost modernost je neodređenosti i nesigurnosti obrazaca društvenog života. Osnovna karakteristika takve modernosti jest konstantna mijena pravila funkcionalnosti na strukturalnoj razini i na razini svakodnevne interakcije i formacije individualnih identiteta. Stabilne kategorije krute modernosti (npr. politika - nacija država, religija, obitelj) više ne pružaju sveobuhvatnu smislenost stvarnosti kao što su to činile prije. U tekućoj modernosti uvjeti društvenog života mijenjaju se brže nego što se produkti promjena ustaljuju u nekom društvu u obliku navika i rutine (Baumann, 2011.). U tom kontekstu može se govoriti i o ubrzanom društvu. Jedina konstanta u ubrzanom društvu jest dinamika (Rosa, 2003.:7). Sukladno navedenom, Rosa (2003.) navodi tri dimenzije ubrzanog društva. Prva dimenzija ubrzanja jest tehnološko ubrzanje. Mogućnost ubrzanja transporta, komunikacije, produktivnosti doveli su do promjena i na planu svakodnevnog života pojedinca. Ono što je karakteristično za tu dimenziju ubrzanja jest kontrakcija prostora i gubljenje signifikantnosti prostora u odnosu na vrijeme (Rosa, 2003.: 6). Sljedeća je dimenzija ubrzanje socijalne promjene. Do ubrzanja dolazi na razini društvenih vrijednosti, mode, oblika organizacije vlastitog života, društvenih odnosa, društvenih grupa, klasa, jezika i odabira profesije. Treća dimenzija društvenog ubrzanja ulazi u okvire svakodnevnog života pojedinca. Potreba da učinimo više stvari u manje vremena vodi do vremenskog pritiskanja pojedinca. Ubrzanje te faze događa se kao rezultat smanjenja obaveza u korist slobodnog vremena.

U svrhu teme ovog rada valja istaknuti potrebu suvremenog društva za porastom učinkovitosti. Što smo učinkovitiji, to možemo odraditi više obaveza, zaduženja i poslova. Ta učinkovitost kao jedna od temeljnih vrijednosti suvremenog društva proizlazi iz svih triju spomenutih dimenzia - tehnologija nam omogućava brže kretanje, komunikaciju izvan prostornih granica, produžetak naših sposobnosti (ako nešto ne znamo, lako guglamo); socijalne promjene - tjeraju nas da neprekidno preispitujemo i razgrađujemo pa nanovo izgrađujemo vlastite identitete. Osobna razina - zbog velikog pritiska svakodnevnog života mora se naći prikladan smisao koji bi bio ekvivalent dinamične požrtvovnosti suvremenog čovjeka. Upravo se zbog te potrebe ne ubrzava samo profesionalni život, već i dokolica. Dokolica je ubrzana zbog potrebe pojedinca za ostvarenjem i zbog pritiska nanovo uspostavljenih vrijednosti da svoje ostvarenje

1 Razumijevajuću sociologiju u naslijeđe je ostavio Max Weber naglašavajući važnost sociologije u razumijevanju djelovanja u okvirima nekog društva (Ritzer, 1997.). 
možemo realizirati samo gomilanjem iskustva - „življenjem svojeg života punim plućima”. Sve to potencijalno dovodi do otuđenja čovjeka od procesa stvaranja smisla prema kolektivnom životu i otuđenja čovjeka od sebe samog. U tom smislu na Rosu se u njegovim analizama može gledati i kao na produžetak kritičke teorije društva. Rosa i Scheuerman (2009) uistinu u daljnjoj analizi ubrzanog društva vide potencijal za otuđenjem. Proces raščaravanja društva doveo je do krutog svijeta. Samo raščaravanje kao pojam, ako se semantički rasloji, označava „svijet koji je prestao pjevati”, svijet odvojen od estetike koju producira čovjekov duh (Rosa, 2017.).

No, Rosa (2019) bijeg od tog otuđenja vidi u ostvarenju rezonance. Rezonanca za njega predstavlja titraj čovjekova duha koji neko iskustvo (u gomili rutinski odrađenih iskustava) prožima individualnim smislom, odnosno ostvarenjem. U tom ostvarenju dolazi do procesa razotuđenja čovjeka ${ }^{2}$. No ovdje se postavlja pitanje: može li rezonanca biti ostvarena usporavanjem dinamičnosti života. Prema Rosi (2017.), usporavanje neće riješiti probleme otuđenja suvremenog čovjeka niti je to usporavanje moguće bez kolapsa suvremenog društva. Rezonanca se mora ostvariti u okvirima ubrzanog života (Rosa, 2017.).

Iako predstavljena teorija odražava određenu razinu epistemološke smislenosti, valja je razmotriti u onom pogledu u kojem dinamičnost i ubrzanje dolaze na vidjelo u najvećoj mogućoj mjerljivoj mjeri - kretanje ljudi u određenom prostoru. Postavlja se pitanje možemo li predstavljenu teoriju vidjeti u praksi kretanja osoba u njihovu svakodnevnom životu. Poseban fokus u tom se kontekstu postavlja na analizu razlika u kretanju tijekom radnog dijela tjedna i tijekom vikenda. Sudeći po teoriji ubrzane modernosti, izvedena je radna hipoteza koja glasi da ne postoji razlika u dinamici kretanja tijekom radnog dijela tjedna i vikendom (koji spada u vrijeme većinski posvećeno dokolici). Radni tjedan spada u dinamiku i kretnju generiranu profesionalnim životom, strukturiranim suvremenim ekonomskim odnosima, dok dokolica spada u osobnu razinu ubrzanja kolektivno vrijednosno određenu (stjecanje velikog broja iskustava i sl.).

\subsection{Upotreba tehnologije GPS-a kao istraživačke metode}

$\mathrm{Na}$ temelju pregleda literature pronađeno je da postoje brojni radovi o upotrebi tehnologije GPS-a u različite svrhe znanstvenih istraživanja. Potencijale te vrste istraživanja prepoznali su autori iz različitih znanstvenih disciplina i profesija od ekonomije (Kawasaki i Axhausen, 2009.:1-3), marketinga (Yue i ostali, 2012.:140-141; Shugan, 2004.:470-474) i turizma (Hardy i ostali, 2017.:255-274) do geografije (Shoval i ostali, 2014.:1-5) i urbanizma (Ratti i ostali, 2006.:727-728). Iz literature proizlazi da se,

2 Pojam razotuđenja prisutan je već u misli Karla Marxa, a često ga je primjenjivao Gajo Petrović, koji je u suvremenom svijetu istovremeno vidio potencijal za otuđenjem, ali i za razotuđenjem. Ipak, sam koncept razotuđenja ili čak i oslobođenja čovjekova duha prema Petroviću (1986.) može biti samo relativan i parcijalan (Petrović, 1986.). 
ovisno o perspektivi iz koje su autori radova krenuli u svoja istraživanja, upotrebom tehnologije GPS-a mogu dobiti podatci korisni za dostizanje brojnih istraživačkih ciljeva, a neki od njih slični su ciljevima ovog rada. Pojedini autori, kao što su Yun i Park (2015.:1246-1265), Hardy i ostali (2017,:255-274) te Shoval i ostali (2014.:1-5), u svojim su radovima opisivali probleme te metodološke prednosti i nedostatke primjene te vrste tehnologije. Neki od utvrđenih problema i nedostatka jesu: (1) etički aspekti te vrste istraživanja; (2) narušavanje privatnosti sudionika; (3) redukcionistička narav rezultata dobivenih uporabom te vrste tehnologije; (4) kompliciran razvoj i nestandardizirana dostupnost platformi s pomoću kojih bi se sudionici mogli pratiti; (5) obujam procedura koje je potrebno obaviti za pripremu terena i za analizu podataka i (6) još uvijek visoka cijena provođenja takvih istraživanja. $S$ druge strane, kao prednosti te vrste istraživanja autori su naveli sljedeće: (1) dobivanje informacija o prostornom i vremenskom kretanju sudionika; (2) mogućnosti da se istražuju različiti geografski prostori i (3) dobivanje velikih baza podataka s puno informacija o sudionicima. Što se tiče mogućih metodoloških potencijala upotrebe te vrste tehnologije u istraživanjima, Versichele i ostali (2014.:44) naveli su da podatci dobiveni s pomoću tehnologije GPS-a imaju velik analitički potencijal, zbog čega je važno raditi na većoj primjenjivosti istraživanja u kojima se takvi podatci mogu koristiti. Na tragu toga mogu se navesti potencijali koje su predstavili i drugi autori: (1) mogućnost stvaranja prediktivnih modela o budućim kretanjima sudionika (Ashbrook i Starner; 2003.:275-278); (2) praćenje kretanja sudionika u stvarnom vremenu (Ratti i ostali, 2006.:727-728) i (3) razvoj novih metoda za analizu velike količine (engl. big data) izvora (Liu i ostali, 2010.:541-548).

Na kraju pregleda literature korisno je opisati raznolikost izvora i metoda koje su autori radova koristili kako bi došli do podataka s pomoću GPS-a i osnovne informacije o različitim populacijama koje su pritom promatrali. Najčešće su upotrijebljeni mobilni telefoni s instaliranim aplikacijama, koje su napravljene za potrebe istraživanja. Pojedini istraživači, kao što su Hardy i ostali (2017.:255-274), razmišljali su o uporabi privjesaka koje bi sudionici nosili sa sobom, ali su zaključili da su mobilne aplikacije korisnije jer sudionici mogu pritom ispunjavati i anketne upitnike ili slične instrumente. Sličnim smjerom išli su Thimm i Seepold (2016.:47-48) u smislu da su se i oni koristili aplikacijom u svojem istraživanju, ali kako bi je učinili privlačnom, u nju su ugradili dodatne opcije, primjerice praćenje sudionika broja vlastitih koraka, $\mathrm{CO}_{2}$ potrošnje, potrošnje kalorija itd. Da nije dovoljno upotrijebiti tehnologiju GPS-a bez dodatnih informacija o sudionicima, zaključio je i Spangenberg (2014.:1-30), koji smatra da je navedenu tehnologiju potrebno kombinirati s putnim dnevnicima, intervjuima „licem u lice", upitnicima itd. Naravno, različiti istraživači pokazali su da je osim mobilnih telefona moguće upotrijebiti i druge tehnologije, a primjer je pronađen kod Yuea i ostalih (2012.:140-141). koji su se za prikupljanje podataka koristili taksijima. Što se tiče istraživanih populacija, kod svih autora pronađeno je da su pratili kretanje više sudionika odjednom bilo u njihovim ulogama običnih građana, potrošača, turista itd., dok je samo kod Ashbrooka i Starnera (2003.:275-278) pronađeno da su proveli pilotistraživanje na jednom sudioniku, čije su kretanje pratili četiri mjeseca (analiza slučaja). 


\section{Ciljevi rada i istraživačka pitanja}

Ciljevi ovog rada jesu (1) predstavljanje mogućnosti primjene tehnologije GPS-a u sociološkoj metodologiji i (2) ispitivanje mogućnosti objašnjenja određenih elemenata teorije ubrzane modernosti upotrebom tehnologije GPS-a.

Sukladno navedenim ciljevima postavljena su istraživačka pitanja: (1.1.) može li se tehnologija GPS-a koristiti kao metodološko sredstvo pri proučavanju pojedinih aspekata društva?; (1.2) koji su osnovni indikatori koji se mogu detektirati korišstenjem podataka dobivenih s pomoću tehnologije GPS-a; (2.1.) mogu li se s pomoću tehnologije GPS-a protumačiti određeni aspekti ubrzanja društvenog života u okvirima teorije ubrzane modernosti? i (2.2.) koje dimenzije teorije ubrzane moderne mogu biti objašnjene kvantitativnim podatcima temeljem korištene metodologije? Rosa (2003.), podsjetimo, navodi tri temeljne dimenzije društvenog ubrzanja. To su tehnološko ubrzanje, ubrzanje društvene promjene i ubrzanje svakodnevnog života. Međutim, pitanje je koje dimenzije tog ubrzanja možemo obuhvatiti upotrebom metodologije GPS-a. Tehnološko ubrzanje dodatno možemo raščlaniti na tri potkategorije. Ubrzanje pokretljivosti (prometa), ubrzanje prijenosa informacija i ubrzanje industrijskih procesa. Iako se tehnološko ubrzanje (u svim trima potkategorijama, a u okvirima ubrzane modernosti) očituje upotrebom tehnologije GPS-a u istraživanju, ono ne može bit znanstveno provjereno metodom na kojoj počiva ovaj rad. Nadalje, ubrzanje društvenih promjena također se ne može izravno povezati s metodom kojom se ovdje koristimo. Dimenzija koja je ovim radom obuhvaćena jest ubrzanje svakodnevnog života pojedinca. Iako širina te dimenzije (kao što će biti vidljivo i u daljnjem tekstu) nadilazi mogućnosti njezina sveobuhvatnog objašnjenja, moguće je prikazati osnovne pokazatelje ubrzanja svakodnevnog života na primjeru koji će detaljnije biti opisan u metodološkim napomenama.

\section{Metodološke napomene}

\subsection{Uzorak}

Za potrebe ovog rada upotrijebljeni su podatci o prostorno-vremenskom kretanju sudionika u istraživanju. Podatci su dobiveni od samih sudionika od kojih se tražilo da na svojim mobilnim uređajima mjesec dana (travanj 2017.) imaju upaljen globalno položajni sustav (GPS). S obzirom na to da je provedeno istraživanje za potrebe ovog rada bilo eksplorativnog, odnosno orijentacijskog tipa, 10 sudionika izabrano je neprobabilističkim uzorkovanjem metodom snježne grude. Važno je naglasiti da svrha ovog rada nije bila generalizacija rezultata na širu populaciju, nego dobivanje odgovora na postavljene ciljeve, u kojima nije uključeno inferencijalno zaključivanje i zbog toga se ta vrsta uzorka može smatrati primjerenom. 
Pri utvrđivanju uzorka u obzir je bilo potrebno uzeti nekoliko činjenica. Prvo, kako bi pojedina osoba bila primjeren ispitanik za uključivanje u istraživanje, trebala je posjedovati mobilni uređaj s mogućnošću namještanja postavki na bilježenje kretanja 24 sata dnevno. Odgovarajuće namještene postavke podrazumijevaju uključen javni servis Google maps i uključenu mogućnost praćenja lokacije. Drugo, pri odabiru pojedinih sudionika tražila se njihova suglasnost, $s$ tim da im je bila dana mogućnost odustajanja od sudjelovanja istraživanja u bilo kojem trenutku. Treće, sudionici koji su pristali sudjelovati u istraživanju bili su okvirno upoznati s temom istraživanja kako bi se spriječile promjene u njihovu ponašanju i u njihovim svakodnevnim aktivnostima.

Što se tiče glavnih zbirnih karakteristika sudionika u istraživanju, uzorak je uključivao šest muškaraca i četiri žene s mjestom prebivališta u Gradu Zagrebu u dobi od 26 do 39 godina. Svi su ispitanici imali mjesto prebivališta u Gradu Zagrebu i svi su bili u radnom odnosu. Šest ih se koristilo automobilom kao glavnim sredstvom prijevoza.

\subsection{Mjerni instrument}

Deset odabranih sudionika sudjelovalo je u istraživanju 30 dana (travanj 2017.) kako bi se dobio konstrukt mjerne jedinice od jednog mjeseca. Podatci dobiveni od sudionika analizirani su s pomoću analitičke matrice, koja je u sebi sadržavala sljedeće varijable: ID sudionika, geografska širina, geografska dužina, datum, dan, mjesec, godina i sat zabilježenih aktivnosti.

\subsection{Metode}

Promatranjem kretanja 10 sudionika ukupno je dobiveno 108235 lokacija definiranih geografskim koordinatama (geografska širina i dužina). Navedeni podatci analizirani su odabranim deskriptivnim statističkim analizama s pomoću statističkog programa za obradu podataka IBM SPSS (verzija 20). Grafički prikazi rezultata napravljeni su s pomoću programa e Microsoft Excel (verzija 2016) i dodatka pod nazivom 3D Map. Svi dobiveni podatci analizirani su skupno kako bi se postigla anonimnost kretanja pojedinih sudionika.

\section{Rezultati}

$\mathrm{Na}$ temelju podataka dobivenih u ovom istraživanju moguće je predstaviti obrasce kretanja sudionika u njihovu svakodnevnom životu. Obrasci se odnose na prostornovremensko kretanje pojedinaca u njihovu okruženju. Svrha je predstavljanja tih rezultata prikaz primjene tehnologije GPS-a u sociološkim istraživanjima svakodnevice na temelju empirijske provjere određenih koncepata teorije o ubrzanoj modernosti. 


\subsection{Prostorno-vremensko kretanje sudionika u njihovom radnom vremenu}

Prema teoriji ubrzane modernosti, svakodnevica pojedinaca počela je izgledati tako da se broj njihovih aktivnosti i količina iskustava koje mogu dobiti povećala u odnosu na prošla vremena (detaljnije objašnjeno u teorijskom dijelu). Ako se krene od pretpostavke da su nečija iskustva povezana s prostorom u kojem živi i vremenom u kojem živi, može se smatrati potrebnim istraživati upravo te segmente nečije svakodnevice. Jedan od načina na koji se može istraži prostor u kojem netko prebiva jest promatranjem kretanja pojedinca u njegovu prostoru, a pritom može pomoći uvođenje novih tehnologija u sociološke istraživačke prakse. Primjena tehnologije GPS-a kao jedan od oblika relativno novih istraživačkih praksi omogućuje dobivanje međusobno povezanih podataka o prostornoj i o vremenskoj dimenziji nečije mobilnosti, a prvi rezultati u ovom radu na tu temu prikazani su u grafikonu 1.

Prvo što se u grafikonu može vidjeti jesu rezultati o frekventnosti kretanja sudionika kroz prostor u odnosu na pojedine sate u promatranim danima (puna linija). Taj pokazatelj izračunat je tako da se promatralo koliko je posto lokacija (prostornih točaka) zabilježeno u svakom pojedinom satu u odnosu na sve zabilježene lokacije u pojedinom danu. Kao takav, taj pokazatelj može poslužiti za dobivanje uvida o tome u kojim se dijelovima dana ili tjedna sudionici istraživanja najviše kreću. Slijedi formula za izračun:

$$
\% \text { koordinata }(\text { sat })=\frac{\mathrm{N} \text { lokacija }(\text { pojedini sat })}{\mathrm{N} \text { lokacija }(\text { pojedini dan })}
$$

Prije tumačenja rezultata potrebno je istaknuti dvije stvari. Prvo, veći postotak lokacija u pojedinom satu označava da su se sudionici više kretali u tom razdoblju (os $y$ ). Drugo, svi prikazani rezultati u ovom i u sljedećim grafikonima podijeljeni su na radne dane (od ponedjeljka do petka) i na dane tijekom vikenda (subota i nedjelja). Svrha takve podjele bila je dobivanje diferenciranog uvida u prostorno i vremensko kretanje sudionika u dijelu tjedna s dinamičnijim životnim tempom (radni dani) i u dijelu tjedna s manje dinamičnim tempom (vikend). 
Grafikon 1.

Frekventnost kretanja sudionika i njihovo zadržavanje u pojedinim prostornim točkama - radni dani

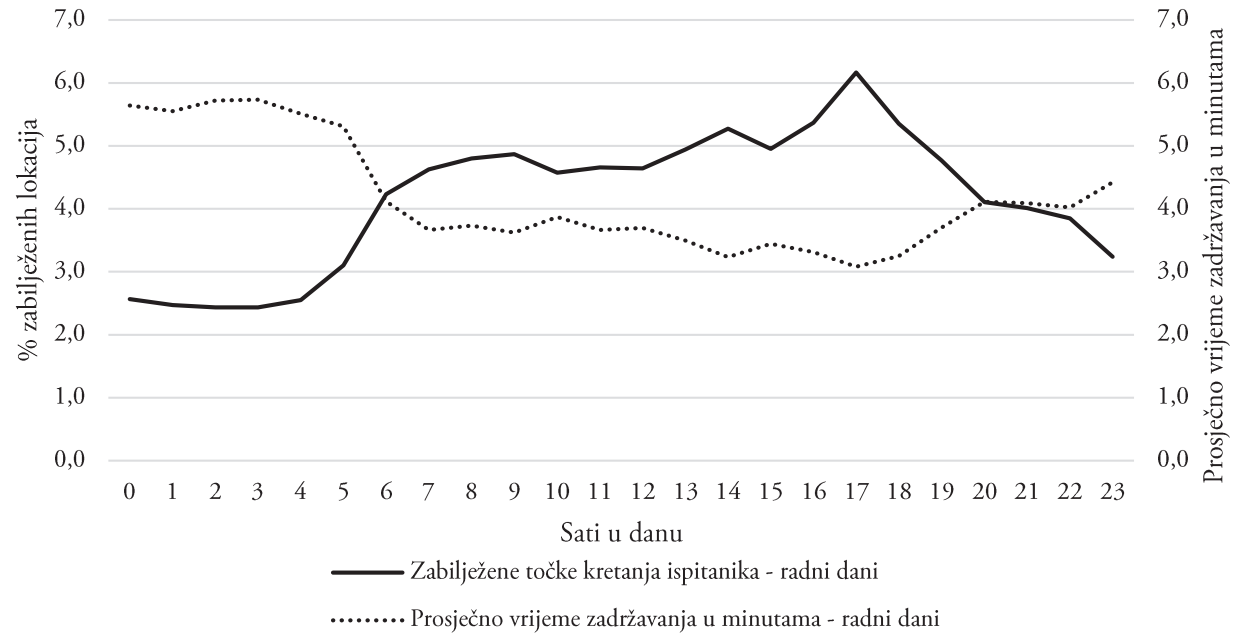

Objašnjenje rezultata možemo započeti promatranjem kretanja sudionika u radnom dijelu tjedna tijekom radnog vremena, što je najčešće od 8 do 16 sati. U grafikonu 1 prikazano je da je u promatranom razdoblju zabilježena veća mobilnost u odnosu na ostale dijelove dana, što se može iščitati na temelju povišenog položaja deblje pune linije uz paralelno postojanje njezina blagog pozitivnog nagiba u tom dijelu dana. Općenito, da mobilnost sudionika nije zabilježena, linija bi bila na vrijednosti 0 osi $y$. Dodatan vizualni prikaz opisane mobilnosti moguće je ponuditi i analizom slike 1 na kojoj crne točkice predstavljaju zabilježene lokacije kretanja sudionika po gradu Zagrebu. Da su sudionici u promatranom periodu bili pretežno na jednom mjestu ili na manjem broju lokacija u prikazu bi se vidjele samo nakupine crnih točaka (lokacija), ali taj prikaz ukazuje na drukčije stanje jer je vidljiva velika raspršenost u njihovim položajima.

Slika 1.

Zabilježeni položaji sudionika od 8 do 17 sati - radni dani

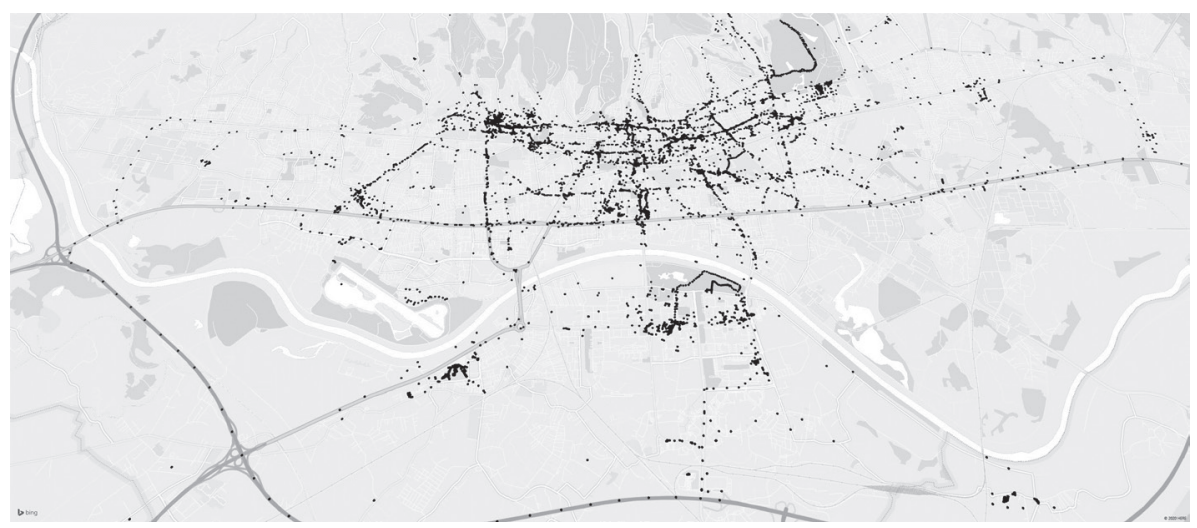


Dalje, iz grafikon 1 uz informacije o prostornom kretanju sudionika moguće je iščitati informacije o njihovu vremenskom zadržavanju u pojedinim prostornim točkama (lokacijama). U grafikonu je taj indikator nazvan „prosječno vrijeme zadržavanja u minutama”. Ta se informacija može smatrati važnom ako se pretpostavi da se frekventnost kretanja sudionika (prvi pokazatelj) smanjuje što se više povećava njihovo zadržavanje u pojedinim prostornim točkama. Demonstracija izračuna tog pokazatelja dostupna je u tablici 1. U prvom koraku izračunata je razlika između vremenskih točaka zabilježenih uz svaku registriranu lokaciju. Npr. lokacija 1 zabilježena je u 11:57:00, dok je lokacija dva zabilježena u 11:58:00, pa je dobivena razlika od jedne minute između tih dviju lokacija. U drugom koraku izračunat je prosjek vrijednosti svih prethodno opisanih razlika tako da je suma svih vrijednosti podijeljena s brojem tih vrijednosti registriranih u svakom pojedinom satu. Npr. (00:01:00+00:03:00)/2=00:02:00. Dobiveni prosjeci prikazani su u grafikonu 1 .

Tablica 1.

Prikaz izračuna prosječnog vremena zadržavanja u minutama

\begin{tabular}{|l|c|c|c|}
\hline \multicolumn{1}{|c|}{ Lokacije } & $\begin{array}{c}\text { Vrijeme evidencije } \\
\text { lokacije }(\mathrm{h})\end{array}$ & $\begin{array}{c}\text { Korak 1: izračun } \\
\text { razlike između } \\
\text { zabilježenih vremena }\end{array}$ & $\begin{array}{c}\text { Korak 2: izračun } \\
\text { prosječnog vremena } \\
\text { zadržavanja u } \\
\text { minutama }\end{array}$ \\
\hline Lokacija 1 & $11: 57: 00$ & - & \multirow{2}{*}{$00: 01: 00$} \\
\hline Lokacija 2 & $11: 58: 00$ & $00: 01: 00$ & \multirow{2}{*}{$00: 01: 30$} \\
\hline Lokacija 3 & $11: 59: 00$ & $00: 01: 00$ & \\
\hline Lokacija 4 & $12: 00: 00$ & - & \\
\hline Lokacija 5 & $12: 01: 00$ & $00: 01: 00$ & \\
\hline Lokacija 6 & $12: 03: 00$ & $00: 02: 00$ & \\
\hline
\end{tabular}

Što se tiče interpretacije samih rezultata, u grafikonu 1 (isprekidana linija) jasno je vidljivo da je prosječno zadržavanje sudionika na pojedinom mjestu u radno vrijeme bilo kraće nego u ostalim dijelovima dana jer isprekidana linija ima tendenciju pada u tom periodu. Drugim riječima, u tom razdoblju frekventnost kretanja sudionika rasla je zbog čega je automatski došlo do pada u njihovu zadržavanju na pojedinim prostornim točkama. Dobiveni rezultati mogu se pojasniti fleksibilnim poslovima ispitanika zbog čega ne moraju imati stanke u točno određeno vrijeme ili određene dužine niti vrijeme moraju provoditi u svojem uredu.

Dodatno obrazloženje prostornog kretanja sudionika tijekom njihova radnog vremena može se ponuditi i na temelju rezultata prikazanih u grafikonu 2 iz kojih proizlazi koliko su se sudionici pomicali u odnosu na geografsku širinu i dužinu koordinata. Drugim riječima, u navedenom grafikonu prikazano je kolike su udaljenosti sudionici prelazili krećući se kroz prostor. Rezultati u grafikonu dobiveni su tako da je izračunata razlika u vrijednostima između svake zabilježene lokacije, koja je opisana geografskom širinom i dužinom te su dobiveni rezultati uprosječeni u odnosu na po- 
jedine sate u danu. Što je dobivena prosječna vrijednost veća, to su veće udaljenosti sudionici prelazili u pojedinom satu. Slijedi formula za izračun (ista formula korištena je za geografsku širinu i dužinu):

$$
\text { Prosjek vrijednosti koordinata }(\text { sat })=\frac{\sum\left(\text { koordinata }_{\mathrm{n}}-\text { koordinata }_{\mathrm{n}+1}\right)}{\mathrm{N} \text { koordinata }(\text { pojedini sat })}
$$

Što se tiče interpretacije rezultata, u grafikonu 2 vidljivo je da su sudionici najveće udaljenosti prelazili u jutarnjem dijelu dana od 6 do 9 sati. To zaključujemo iz činjenice da se linije u grafikonu u tom razdoblju najviše udaljavaju od vrijednosti 0 , koja ukazuje na to da pomaci nisu zabilježeni. Pomaci linija mogli su se odvijati u pozitivnom i negativnom smjeru jer to ukazuje na to da su se ispitanici kretali u smjerovima sjever - jug i/ili zapad - istok.

\section{Grafikon 2.}

Kretanje sudionika u odnosu na vrijednosti geografske širine i dužine njihova kretanja - radni dani

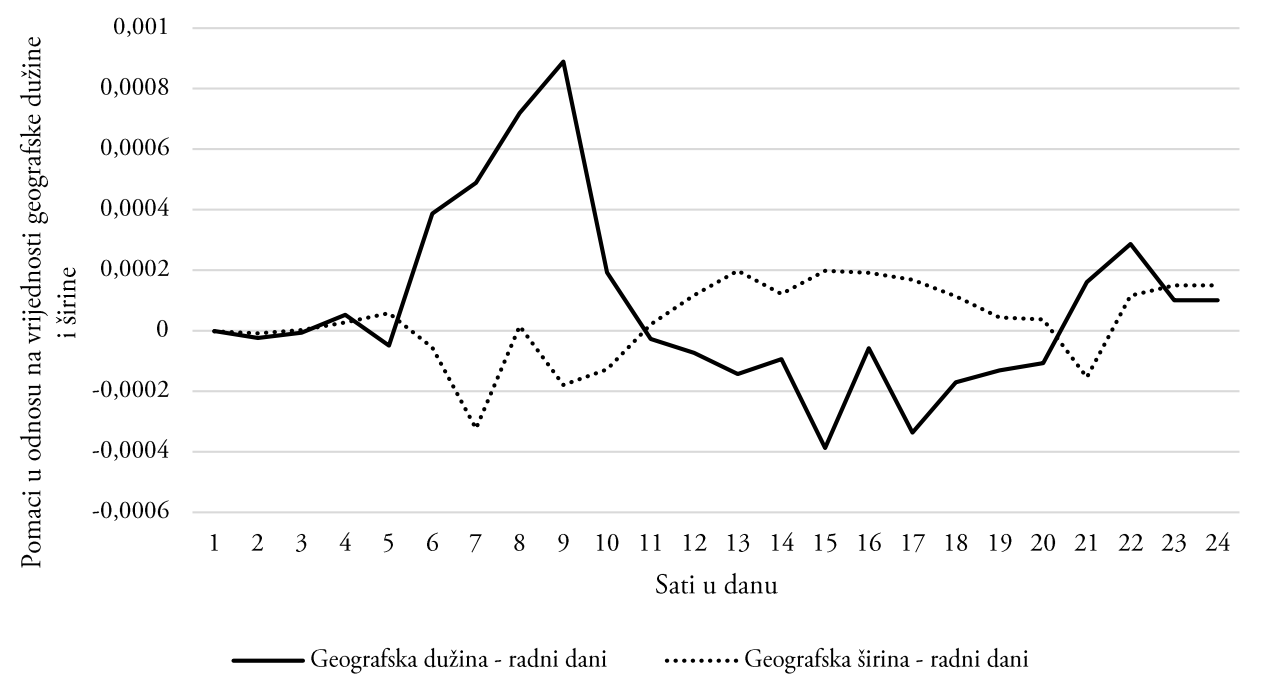

Smatrano da smo dosad opisanim rezultatima pokazali kako se podatci GPS-a mogu upotrijebiti za analitičko, grafičko i slikovno objašnjenje nečijeg prostornog kretanja u točno određenom vremenu. Također, iz tih rezultata moglo bi se zaključiti da je došlo do ubrzanja svakodnevice pojedinaca, barem u promatranim razdobljima. Detaljnija interpretacija rezultata i njihovo povezivanje s teorijom može se pronaći u poglavlju Rasprava.

Iako za sada postoje pokazatelji da se koncepti iz promatrane teorije mogu primijeniti na sudionike iz ovog istraživanja (s obzirom na njihove karakteristike), uslijedit će rezultati u kojima će se pokazati da tome nije uvijek tako. 


\subsection{Prostorno-vremensko kretanje sudionika u vrijeme njihove dokolice}

U ovom poglavlju slijedi dio rezultata o mobilnosti sudionika u vrijeme njihove dokolice, tj. njihovo kretanje u dijelovima dana izvan standardnog radnog vremena. Promatranje sudionika u njihovoj dokolici važno je ako se empirijski žele ispitati svi dijelovi teorije o ubrzanoj modernosti. Naime, slijedeći upravo navedenu teoriju, autori rada krenuli su od pretpostavke da je moguće empirijski pokazati da će sudionici u svojoj dokolici, tj. tijekom vikenda imati ubrzaniji svakodnevni život, barem u odnosu na radne dane u tjednu. Međutim, kao što se iz grafikona 3. može vidjeti, ta pretpostavka ne stoji.

\section{Grafikon 3.}

Frekventnost kretanja sudionika i njihovo zadržavanje u pojedinim prostornim točkama - radni dani i vikend
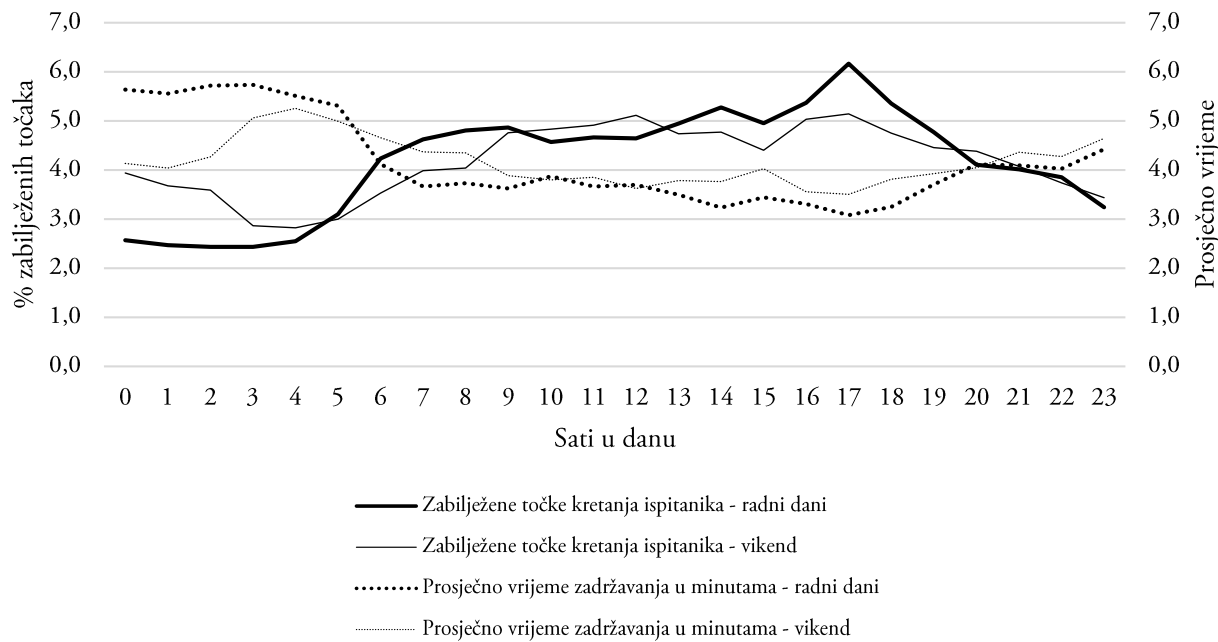

U grafikonu 3 vidljivo je da je prostorno kretanje sudionika bilo jednakog ili čak i manjeg intenziteta tijekom najvećeg dijela dana subotama i nedjeljama (tanja puna linija) u odnosu na radne dane (deblja puna linija). Tim se rezultatom, kao i prethodnim rezultatima, pokazujeda je moguće vremenski odvojiti i prostorno pratiti sudionike i tijekom njihove dokolice, a njegova detaljnija teorijska interpretacija može se pronaći u poglavlju Rasprava.

Smanjenje mobilnosti sudionika u vrijeme njihove dokolice također se može vidjeti na slikama 2 i 3 . Na njima su prikazani podatci o prostornoj mobilnosti sudionika od 18 do 23 sata, što je razdoblje koje se može smatrati dokolicom tijekom svih dana u tjednu. Tijekom radnih dana (slika 2) zabilježena je puno veća mobilnost sudionika u odnosu na to isto razdoblje tijekom vikenda (slika 3), kada se moglo očekivati da će mobilnost pojedinaca u njihovoj potrazi za novim podražajima i iskustvima biti jednaka ili veća od one tijekom radnog dijela tjedna. 
Slika 2.

Zabilježeni položaji sudionika od 18 do 23 sata - radni dani

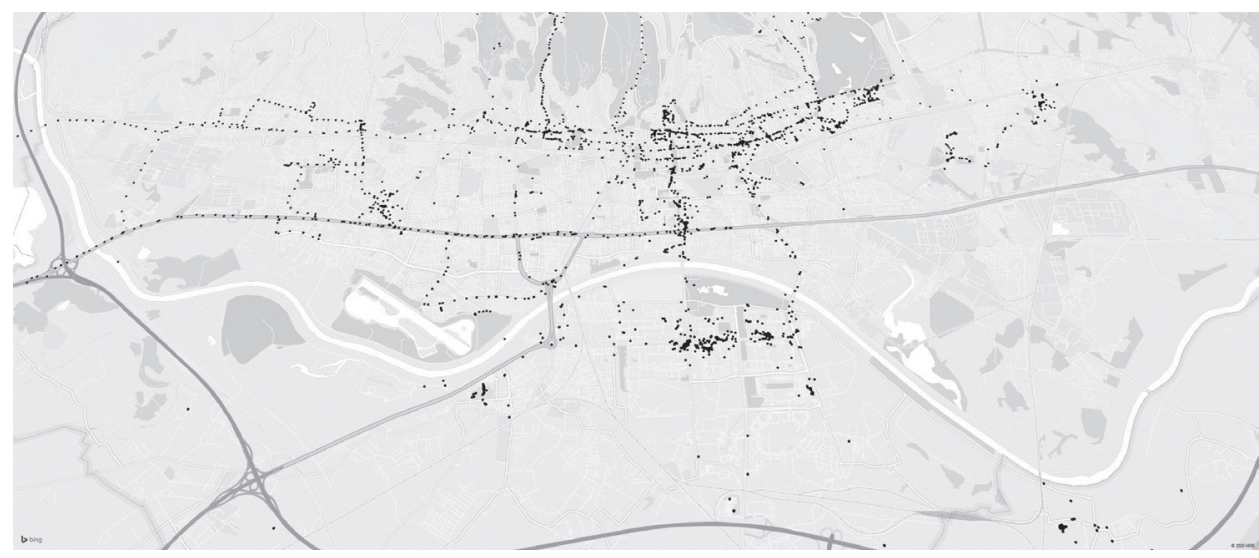

Slika 3.

Zabilježeni položaji sudionika od 18 do 23 sata - vikend

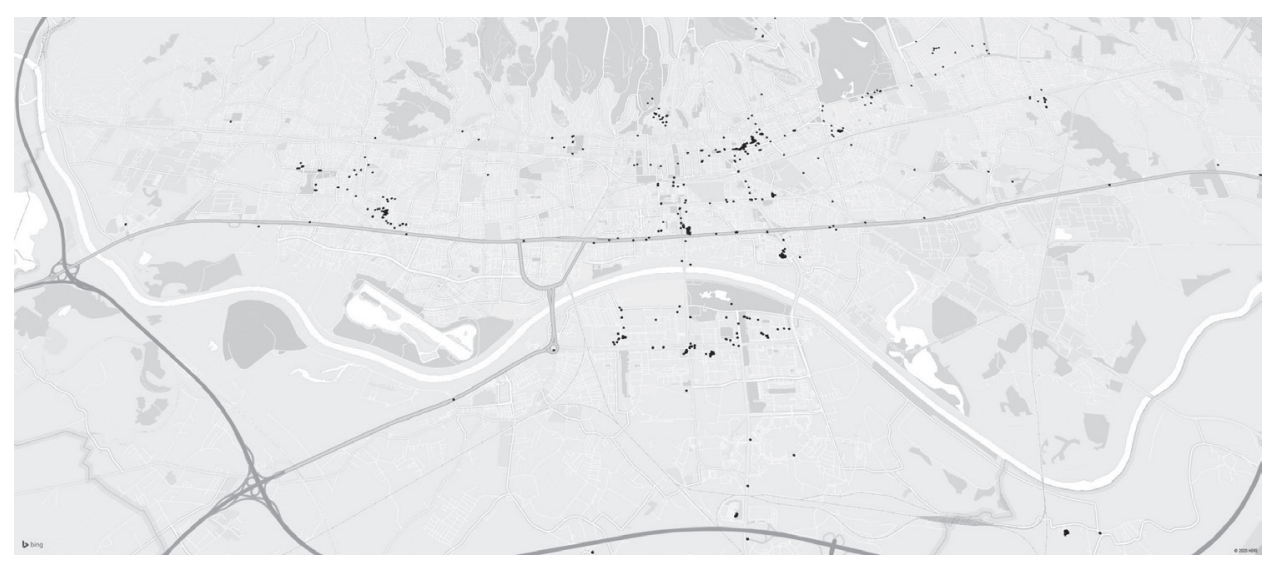

Na slici 3 prevladavaju nakupine crnih točkica (lokacija), što ukazuje na činjenicu da su sudionici prvotno bili smješteni na manjem broju lokacija u promatranom razdoblju. Taj rezultat može se tumačiti na dva načina. Razdoblje od 18 sati nadalje tijekom radnih dana može se smatrati vremenom za dokolicu, ali i vremenom za obavljanje različitih svakodnevnih obaveza ili putovanje s posla prema domu. Pretpostavka je da je zbog navedenih razloga zabilježen veći intenzitet kretanja sudionika prikazan na slici 2. Za razliku od toga, to isto razdoblje tijekom vikenda pokazalo se kao vrijeme u kojem sudionici nisu bili mobilni, što se može objasniti pretpostavkom da nisu imali obaveze ili aktivnosti kojima ispunjavaju slobodno vrijeme i koje bi od njih zahtijevale veću prostornu mobilnost.

Završit ćemo s tumačenjem rezultata predstavljenih u grafikonu 4 u kojem je prikazana ista vrsta informacija kao i u grafikonu 2, ali ovaj je put promotreno kako su 
se sudionici kretali (kolike udaljenosti su prolazili) u odnosu na geografsku širinu i dužinu tijekom vikenda. Uspoređujući ta dva grafikona uočava se da su sudionici tijekom vikenda prelazili puno manje udaljenosti nego tijekom radnih dana (linije su blizu vrijednosti 0 ), i to više-manje tijekom cijelog vikenda, osim u večernjim satima u kojima je došlo do povećanja prijeđenih udaljenosti. Ti rezultati također idu u prilog prethodno opisanoj pretpostavci da prostorna dimenzija kretanja ne može poslužiti kao jedini indikator za objašnjenje kako pojedinci dolaze do novih iskustava tijekom svojih dokolica, a detaljnije o tome u raspravi.

Grafikon 4.

Kretanje sudionika u odnosu na vrijednosti geografske širine i dužine njihova kretanja - vikend

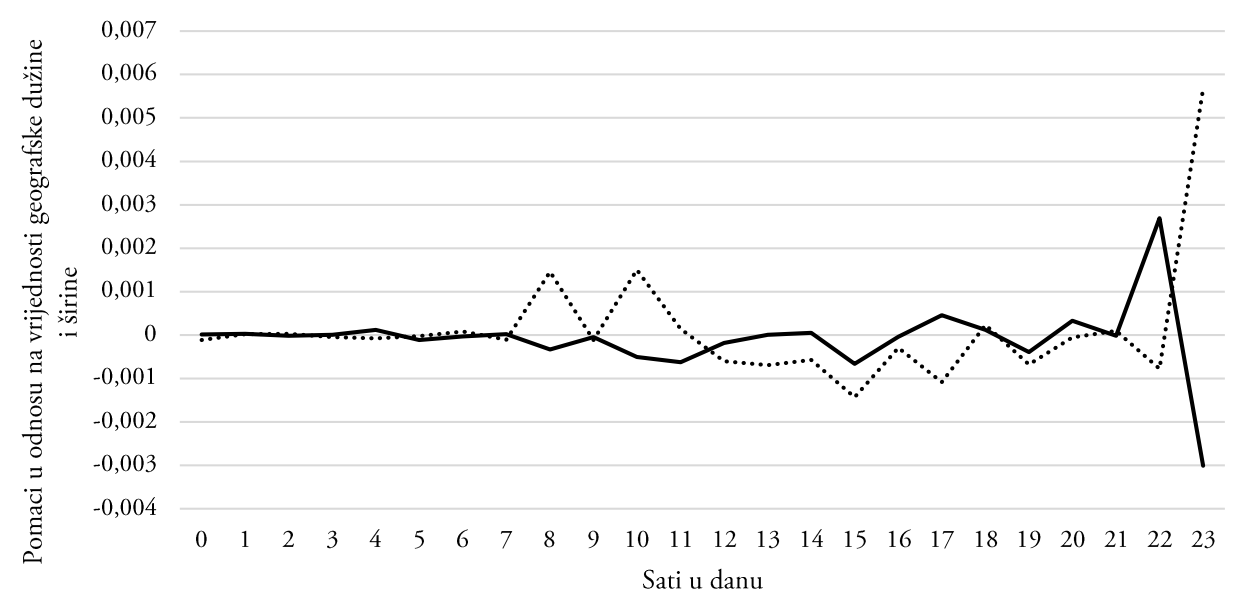

— Geografska širina - vikend Geografska dužina - vikend

\subsection{Prostorno-vremensko kretanje sudionika u odnosu na mjesto stanovanja}

S obzirom na prethodno predstavljene rezultate, prema kojima su sudionici bili manje mobilni u svoje slobodno vrijeme, postavljaju se dodatna pitanja o izvorima i načinima dobivanja novih iskustava u vrijeme njihove dokolice. Stoga ćemo prikaz rezultata završiti podatcima koji mogu pomoći u odgovaranju na ta pitanja, a istovremeno ćemo prikazati još jedan način upotrebe tehnologije GPS-a u istraživačke svrhe. Rezultati koji slijede prikazuju prostornu mobilnost sudionika u odnosu na njihovu adresu stanovanja, tj. koliko su se udaljavali od mjesta stanovanja u svoje slobodno vrijeme.

U grafikonu 5 prikazano je kretanje sudionika u promjeru od $200 \mathrm{~m}$ oko njihova mjesta stanovanja. U tom grafikonu mogu se vidjeti dvije linije, $s$ tim da puna linija predstavlja kretanje ispitanika vikendom, a iscrtana linija predstavlja njihovo kretanje tijekom radnih dana. Rezultati prikazani tim grafikonom dobiveni su tako da se promatralo koliko je posto lokacija registrirano u promjeru od $200 \mathrm{~m}$ od mjesta sta- 
novanja svakog ispitanika u odnosu na sve njegove registrirane lokacije u pojedinom satu svakog dana. Grafikon se tumači na način da viši položaj linije na osi y ukazuje na činjenicu da su se sudionici više kretali oko svoje adrese stanovanja. Na primjer, u grafikonu je vidljivo da je od ponedjeljka do petka između ponoći i 5 sati ujutro registrirano više od $90 \%$ lokacija unutar $200 \mathrm{~m}$ od mjesta stanovanja sudionika, što znači da su u to vrijeme bili u svojim domovima ili u neposrednoj blizini. Za razliku od prethodnog rezultata, u grafikonu je također vidljivo da su sudionici najmanje vremena provodili u neposrednoj blizini svojeg mjesta stanovanja u popodnevnim satima, bilo tijekom radnih dana (puna linija) ili tijekom vikenda (isprekidana linija), s tim da su se tijekom vikenda manje udaljavali od te prostorne točke. Na kraju se može reći da su sudionici tijekom radnih dana u prosjeku proveli 54,9\% vremena u krugu od $200 \mathrm{~m}$ oko svojeg mjesta stanovanja (S.D.=26,67), dok je tijekom vikend ta vrijednost iznosila 56,6 \% od svih zabilježenih lokacija (S.D.=12,09).

Dobiveni rezultati mogu se smatrati korisnim informacijama za konkretnije određivanje načina ili barem mjesta na kojem pojedinci u svoje slobodno vrijeme dobivaju nova iskustva jer se pokazalo da se sudionici u istraživanju nisu uvelike udaljavali od svojeg mjesta stanovanja ako to nije bilo neophodno (npr. zbog radnih obaveza). Iako dobiveni rezultati mogu biti korisni u budućim istraživanjima, njihova je ograničenost očigledna. Ograničen spoznajni karakter dobivenih podataka glavni je uteg tog tipa istraživanja, ali više o tom problemu i kako ga riješiti reći ćemo u raspravi.

\section{Grafikon 5.}

Zastupljenost prostornih točaka kretanja sudionika u promjeru od $200 \mathrm{~m}$ oko njihova mjesta stanovanja - relativno u odnosu na ukupan broj točaka (lokacija) u pojedinom satu

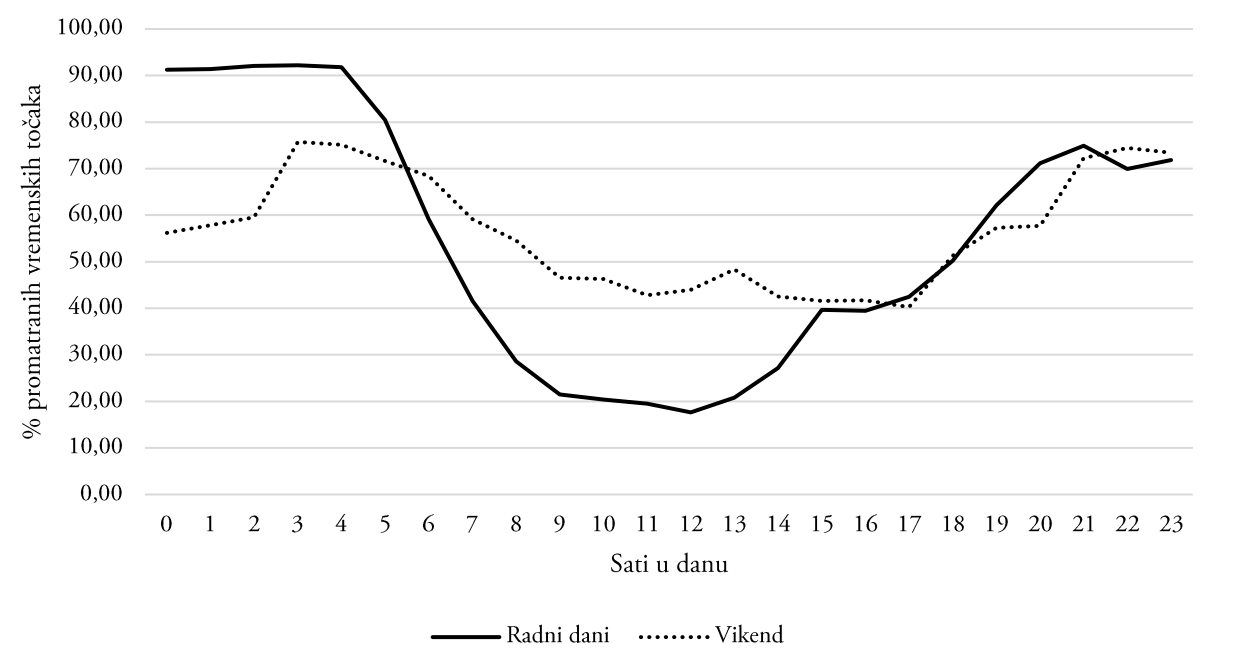




\section{Rasprava}

Tehnologiju GPS-a ne obilježava samo funkcionalnost u svakodnevnom životu. Iz dobivenih rezultata vidljiva je primjena te tehnologije u znanstvenim okvirima - prije svega u određivanju prostorne dinamike društvenog života. Sociologiji kao znanosti o društvu, održavajući korak s razvojem suvremene tehnologije, omogućuje se širenje spoznaja o različitim oblicima mikrodjelovanja, o razvoju i promjenama društvenih struktura i procesa. Konkretan metodološki doprinos upotrebe tehnologije GPS-a može se uočiti u razmatranju kretanja pojedinaca u urbanim (ali i ruralnim) prostorima. Prostornost je, unatoč novim virtualnim dimenzijama stvarnosti, i dalje važan aspekt čovjekova života. Klasični mikrosociološki orijentirani teoretičari (Goffman, Berger, Luckmann) komunikaciju „licem u lice” smatrali su važnom za značenjsko ostvarenje zbilje. Intersubjektivnost po njima moguće je postići u okvirima bivanja ovdje i sada (Zhao, 2006.). Iako se ta spoznaja o interakciji, od Bergerova i Luckmannova razdoblja, značajno proširila, ostaju neistražene dimenzije fizičkog djelovanja pojedinca. Upotrebu te metodologije mogu se obuhvatiti određeni aspekti tog društvenog fenomena - bivanja pojedinca u prostoru. Drugim riječima, da bismo razumjeli snalaženje čovjeka u prostoru (uključujući i prostor društvenosti), sociolozi trebaju usvojiti korisne alate koje su im dostupni zbog tehnološkog razvoja. Upotreba tehnologija GPS-a ipak ima svojih mana. Ona naime može pružiti spoznaju o različitim aspektima kretanja pojedinca i/ili provođenja privatnog i poslovnog vremena (npr. vrijeme provođeno u trgovačkim centrima, u prirodi itd.), ali ne može prodrijeti u značenjske dimenzije tog djelovanja. Dakle, tehnologija GPS-a s jedne strane omogućuje gotovo pozitivistička saznanja - koja nas približavaju traženju svojevrsnih zakonitosti kretnje, ali s druge strane ne pomaže nam odgovoriti na pitanja zašto se ljudi kreću određenim prostorima ili mjestima - dominiraju li kulturni obrasci njihovim odlukama i formiranjem značenja posjeta određenih mjesta (na čemu se temelji i kritika te metode opisana u poglavlju Dosadašnja istraživanja) i na koje načine organiziraju vrijeme u svojem danu i zašto? Stoga, ako se budućim istraživanjima koja uključuju GPS doda kvalitativno istraživanje, tada mogu biti metodološki korisna pri proučavanju prostornih elemenata u sociologiji.

S druge strane, u ovom je radu, uz metodološki karakter, dobivenim podatcima preispitana i mogućnost provjere određenih aspekata teorije ubrzane modernosti. Sociološke teorije, naime, skup su alata kojima se mogu opisati određeni društveni procesi u zadanom kontekstu (Županov, 1995.). Teorije valja koristiti u tom smislu kao pokazatelj u određivanju i razumijevanju fenomena - pri konceptualizaciji mogućih empirijskih podataka, ali i kao dodatna vrijednost, odnosno kao onaj razumijevajući faktor dobivenih empirijskih podataka. Time se zapravo izlazi u susret i onome što je Max Weber smatrao da je osnovna zadaća sociologije kao znanosti, a to je razumijevanje (vidi Weber, 1989.).

U kontekstu ovog rada mogu se uočiti svojevrsni trendovi akceleracije svakodnevnog 
života pojedinaca koji žive u urbanim sredinama sa suvremenim tipom radnih mjesta (prilagodljivo radno vrijeme, dinamika kretanja u prostoru - sastanci, seminari itd.). Iz rezultata je vidljivo kako pojedinci, koji su praćeni tehnologijom GPS-a, slijede ustaljene obrasce vremenitosti vlastitog kretanja, no osnovno obilježje kretanja u radnom tjednu (ili radnom danu) jest dinamično. Drugim riječima, iako se u radnom tjednu kreću manje-više u slično vrijeme, kretanje je dinamično i raspršeno u prostoru. Također, iako se najviše vremena sudionici zadržavaju na određenim stabilnim lokacijama (kao što je ured), kretanje se ne zaustavlja samo na putovanju od kuće do ureda., već se posjećuju lokacije koja se dokida rutina. U okvirima teorije ubrzane modernosti to bi se moglo objasniti na način da je jedina rutina suvremenih poslova, ali i suvremenih pojedinaca koji žive u urbanim prostorima (tijekom radnog dijela tjedna) stalna dinamika kretanja. Tijekom radnog dana rutina postoji, no prilagođena je dinamici radnog mjesta u većoj mjeri negoli je radno mjesto prilagođeno toj rutini. Tako se npr. stanka ili odlazak na ručak nije mogao označiti u jednom ustaljenom obrascu - već je odlazak na ručak ovisio o dinamici dana.

No suprotnost radnom tjednu u empirijskim je podatcima vikend, odnosno subota i nedjelja. U tom razdoblju dinamika se smanjuje, a veći broj sudionika istraživanja svoje je vrijeme provodilo u svojem domu. Postojala je relativno mala dinamika kretanja. Stoga valja postaviti pitanje: kako se taj podatak može objasniti u okviru teorije ubrzane modernosti? Na to se pitanje ne može odgovoriti empirijskim podatcima, no mogu se postaviti dvije hipoteze utemeljene na sintezi razrađene teorije i empirijskih podataka. Prvo, nerazmjernost dinamike tijekom vikenda i radnog dijela tjedna u kontekstu pretpostavke ubrzanog društva može biti objašnjeno težnjom pojedinca za usporavanjem. Drugim riječima, tijekom radnog dijela tjedna iskustva interakcije i kretanja na visokoj su razini. Pojedinac tada vrši velik broj interakcija i suočava se $s$ velikim brojem različitih iskustava (na poslovnom i privatnom planu). U inflaciji iskustava za vrijeme dokolice pojedinac teži usporavanju barem trenutnom. Pojedincu je potrebno vrijeme za sebe u kojem je refleksivnost prema drugima u fazi mirovanja. Drugo objašnjenje ili moguća hipoteza ide u prilog teoriji ubrzane modernosti (u kojoj usporavanje nije opcija). To objašnjenje povezuje se i s nedostatcima istraživanja. Osnovni nedostatak, naime, bio je taj da se u istraživanju bilježio samo GPS, odnosno prostor zadržavanja bez saznanja o tome što pojedinci u određenom trenutku rade. Tako se u ovom istraživanju ostanak kod kuće vikendima može pokušati objasniti time da se fizički prostor transcendira i da se iskustvo traži u prostoru virtualne stvarnosti (ili stvarne virtualnosti, kako je definira Castells, 2010.). Fluktuacija i dinamika, odnosno ubrzanje iskustava u tom slučaju ne ovisi o kretanju. Pojedinac i njegov GPS stoje na mjestu, ali se kreću i razmjenjuju iskustva, u interakciji su, uče nešto novo $s$ pomoću interneta ili drugih medija. Iako to na prvi pogled djeluje kao odmor, ono i dalje ide u prilog dinamici i ubrzanju svakodnevnog života. Iako se prostorno ne krećemo, žudimo za kontrakcijom vremena u korist onoga što ćemo iskusiti. Dakle, empirijskim podatcima u ovome istraživanju mogli smo obuhvatiti samo prostorne i 
vremenske elemente ubrzanog društva. Za šire objašnjenje podataka i samog fenomena ubrzanog društva, svakako su potrebna dodatna istraživanja - prvenstveno kvalitativnog tipa, u kojima bi se naznačilo o kakvom je (ne)kretanju riječ, kakva iskustva pritom nastaju i koja su njihova značenja.

\section{Zaključak}

Ovaj rad imao je dva cilja. Prvi cilj rada bio je predstavljanje mogućnosti upotrebe sustava GPS u okvirima sociološke metodologije. Upotreba metodologije GPS-a metodologije može biti korisno sredstvo za proučavanje društvenih procesa u okvirima posebnih sociologija kao što su sociologije grada, sociologije sela, sociologije potrošnje itd. Zadatak je sociološke struke, ali i same znanosti da se koristi suvremenim tehnološkim dostignućima kako bi olakšala i unaprijedila vlastite spoznaje. Znati i razumjeti društvo, društvene procese i društvenu interakciju, društvenu dinamiku zadaća je sociologije od njezinih početaka. Tehnologijom GPS-a može se dobiti uvid u osnovne crte socio-prostorne dinamike. Ovim radom ne podcjenjuju se mogućnosti klasičnih metodoloških sredstava, ali se istima pridružuju tehnološka sredstva kojima se klasična metodologija proširuje u svojim rezultatima. No, ako gledamo konkretnije, na temelju ovoga rada zaključujemo kako je tehnologija GPS-a i njezina upotreba u metodološkom smislu višedimenzionalna i korisna za sociologiju prostora. Konkretno, korisnost GPS-a u sociološkom proučavanju prostora može se definirati četirima točkama. Prvo, sudionike istraživanja moguće je pratiti kroz prostor i vrijeme - moguće je otkriti načine na koje pojedinci ovladavaju prostorom i u kojem vremenu. Nadalje, moguće je razlikovati kretanje pojedinaca tijekom pojedinih dijelova dana i tjedna te ih analitički zasebno tumačiti i/ili međusobno ih uspoređivati. Treće, moguće je dobiti podatke o tom kolike udaljenosti sudionici tijekom istraživanja prelaze - moguće je pratiti dinamiku i opseg kretanja u svakodnevnom životu (u stvarnom vremenu). Na posljetku, moguće je gledati prostorno-vremensko kretanje sudionika u odnosu na pojedine referentne točke u prostoru (npr. kretanje od mjesta stanovanja, posla, kretanje tijekom vikenda itd.). S obzirom na univerzalnost dobivenih rezultata, autori istraživanja zaključuju kako je za potrebe ovog rada bilo sporedno koje vrijeme i koji prostor su se istraživali s pomoću tehnologije GPS-a. U ovom su slučaju to bili podatci za Grad Zagreb iz 2017., pri čijoj bi se interpretaciji kroz društvenu prizmu promatrao kontekst tog trenutka, ali ta vrsta interpretacije nije bila od primarnog interesa za ovaj rad. Nadalje, pri upotrebi tehnologije GPS-a u sociološkim istraživanjima uvijek valja imati na umu etičke dimenzije istraživačkog procesa, ali i potencijalne opasnosti za privatnost pojedinaca. Upravo je etičnost ovakvih istraživanja područje koje valja šire ispitati i definirati. Analizirane funkcionalnosti upotrebe tehnologije GPS-a u istraživanjima mogu ostati u sjeni etičke problematičnosti. Iz tog razloga, prije šire upotrebe te tehnologije u metodološkim radovima, uz ovakav tip analize funkcionalnosti, moraju se učiniti značajni napori u strukturiranju etičnosti ovakvog tipa istraživanja. 
Drugi cilj istraživanja bio je ispitati mogućnosti objašnjenja određenih elemenata teorije ubrzane modernosti upotrebom tehnologije GPS-a. Upotrebom te metodologije mogu se istražiti dimenzije ubrzanja svakodnevnog života pojedinaca (u ovom slučaju u okvirima urbanog prostora Grada Zagreba). Kao što je prethodno opisano, to ubrzanje se na taj način može analizirati samo u stvarnim vremensko-prostornim dimenzijama. Iako su i takvi podatci važni za otkrivanje određenih karakteristika modernog načina života, izvan dosega tehnologije GPS-a ostaje dinamika koja se događa izvan prostornih okvira. Ipak, uz već spomenute nedostatke, metodologija GPS-a u sintezi $s$ teorijom ubrzane modernosti daje bogata saznanja o svakodnevici suvremenog čovjeka, te može biti pokretač dodatnih istraživanja drugim metodološkim alatima (npr. kvalitativno istraživanje). Upravo se u tome očituje glavni nedostatak ovoga rada, a to je metodološka jednodimenzionalnost. U budućim istraživanja preporuka je da se tehnologija GPS-a kombinira s drugim metodama kako bi se postigle više razine spoznaje.

\section{Literatura}

1. Ashbrook, D. nad Starner, T. (2003). Using GPS to learn significant locations and predict movement across multiple users. Personal and Ubiquitous Computing, 7: 275-286. doi: 10.1007/s00779-003-0240-0.

2. Baumann, Z. (2011). Tekuća modernost. Zagreb: Naklada Pelago.

3. Beck, U. (2001). Rizično društvo: U susret novoj moderni. Beograd: „Filip Višnjič".

4. Castells, M. (2010). The Rise of the Network Society. Wiley-Blackwell.

5. Cifrić, I. (1995). Sociologija u novom socijalnom kontekstu. Društvena istraživanja, 4 (2-3 (16-17)): 241-264.

6. Giddens, A. (2005). Odbjegli svijet: kako globalizacija oblikuje naše živote. Zagreb: Jesenski i Turk.

7. Hardy, A.; Hyslop, S.; Booth, K.; Robards, B.; Aryal, J.; Gretzel, U.; Eccleston, R. (2017). Tracking tourists' travel with smartphone-based GPS technology: a methodological discussion. Information Technology \& Tourism, 17 (3): 255-274.

8. Kawasaki, T. and Axhausen, K. W. (2009). Choice set generation from GPS data set for grocery shopping location choice modelling in canton $\mathrm{Zu}$-rich: Comparison with the Swiss Microcensus 2005. Arbeitsberichte Verkehrs Und Raumplanung, 595: 1-3. doi: 10.3929/ethz-a-005939093.

9. Latour, B. (2005). Reassembling the Social: An Introduction to Actor-NetworkTheory. Oxford: Oxford University Press.

10. Liu, L.; Andris, C. and Ratti, C. (2010). Uncovering cabdrivers' behavior patterns from their digital traces. Computers, Environment and Urban Systems, 34 (6): 541-548. doi: 10.1016/j.compenvurbsys.2010.07.004.

11. Petrović, G. (1986). Filozofija prakse. Zagreb: Naprijed. 
12. Ratti, C.; Frenchman, D.; Pulselli, R. M.; Williams, S. (2006). Environment and Planning B: Urban Analytics and City Science. Mobile Landscapes: Using Location Data from Cell Phones for Urban Analysis, 33: 727-748. doi: 10.1068/ b32047.

13. Ritzer, G. (1997). Suvremena sociologijska teorija. Zagreb: Nakladni zavod Globus.

14. Rosa, H. (2003). Social Acceleration: Ethical and Political Consequences of a Desynchronized High-Speed Society. Constellations, 10 (1): 3-33.

15. Rosa, H. and Scheuerman, W. E. (2009). High-Speed Society - Social Acceleration, Power and Modernity. Pennsylvania: Pennsylvania State University Press.

16. Rosa, H. (2017). Do We Really Live in an Acceleration Society? Predavanje na London School of Economics and Political Science. https://www.youtube.com/ watch?v=VHk1iPvujic\&t=1128s. (Pregledano 14.05.2020.)

17. Rosa, H. (2019). Resonance: A Sociology of Our Relationship to the World. Cambridge: Polity Press.

18. Shoval, N.; Kwan, M.; Reinau, K. H.; Harder, H. (2014). The shoemaker's son always goes barefoot: Implementations of GPS and other tracking technologies for geographic research. Geoforum, 51: 1-5. doi: 10.1016/j.geoforum.2013.09.016.

19. Shugan, S. M. (2004). The Impact of Advancing Technology on Marketing and Academic Research. Marketing Science, 23 (4): 470-474. doi: 10.1287/ mksc.1040.0096.

20. Spangenberg, T. (2014). Development of a Mobile Toolkit to Support Research on Human Mobility Behavior Using GPS Trajectories. Inf Technol Tourism, 14 (4): 1-30. doi: 10.1007/s40558-014-0005-9.

21. Thimm, T. and Seepold, R. (2016). Past, present and future of tourist tracking. The Journal of Tourism Futures, 2 (1): 43-55. doi: 10.1108/JTF-10-2015-0045.

22. Versichele, M.; de Groote, L.; Bouuaert, M. C.; Neutens, T.; Moerman, I.; Van de Weghe, N. (2014). Pattern mining in tourist attraction visits through association rule learning on Bluetooth tracking data: A case study of Ghent, Belgium. Tourism Management, 44: 67-81. doi: 10.1016/j.tourman.2014.02.009.

23. Weber, M. (1989). Metodologija društvenih nauka. Zagreb: Globus.

24. Yue, Y.; Wang, H.-dong; Hu, B.; Li, Q.-quan; Li, Y.-guang; Yeh, A. G. O. (2012). Exploratory calibration of a spatial interaction model using taxi GPS trajectories. Computers, Environment and Urban Systems, 36 (2): 140-141. doi: 10.1016/j.compenvurbsys.2011.09.002.

25. Yun, H. J. and Park, M. H. (2015). Time-Space Movement of Festival Visitors in Rural Areas Using a Smart Phone Application. Asia Pacific Journal of Tourism Research, 1246-1265. doi: 10.1080/10941665.2014.976581.

26. Zhao, S. (2006). The Internet and the Transformation of the Reality of Everyday Life: Toward a New Analytic Stance in Sociology. Sociological Inquiry, 76 (4): 458-474.

27. Županov, J. (1995). Poslije potopa. Zagreb: Nakladni zavod Globus. 


\title{
The Possibilities of Applying GPS Technology in Sociological Research
}

\author{
Josip Ježovita \\ Catholic University of Croatia, Zagreb, Croatia \\ e-mail: josip.jezovita@unicath.hr \\ Erik Brezovec \\ University of Zagreb, Faculty of Croatian Studies, Croatia \\ e-mail:ebrezovec@hrstud.hr \\ Lucija Mihaljević \\ Catholic University of Croatia, Zagreb, Croatia \\ e-mail: lucija.mihaljevic@unicath.hr
}

\begin{abstract}
In this theoretical-research work, the possibilities of using GPS methodology in research in the field of social sciences are analyzed. The paper is characterized by two fundamental aims. The first is to present the different ways of applying GPS technology in research practice and on that basis to present the range of knowledge that can be achieved by using this technology and method. The second aim is oriented towards the analysis of the practical validity of the theory of accelerating modernity. This set of theories, although relatively abstract, can be confirmed by certain empirical ventures. One of such ventures is this research which uses GPS technology to investigate the dynamics of the movement of individuals in the urban space of the City of Zagreb. With the use of this technology, it is possible to analyze the dynamics of movement with respect to the spatial-temporal context. The method of this study was to track study participants via their smartphones with a built-in GPS system. 10 survey participants agreed to track their GPS over a 30-day period. The results of the research show different dynamics of movement. Namely, participants showed a high level of spatial dynamics in a condensed time frame during the work week (which supports the theory of accelerating modernity), while they spent more time in their homes over the weekend. The research sets 4 dimensions, among others, that can be covered by GPS technology within the social sciences and sets methodological guidelines about combining GPS technology with other methods.
\end{abstract}

Key words: GPS, methodology, accelerating modernity, spatial dynamics. 